\title{
Game Intelligence: From Animal Play Behavior to Entertainment Computing
}

\author{
Marion Bönsch-Kauke \\ Ahrenshooper Str. 33/0501, 13051 Berlin, Germany \\ Marion.Boensch-Kauke@gmx.de
}

\begin{abstract}
Playing a game, cooperative, competitive or mixed motive, keeps our attention; good vibrations and a sense of humor 'arouse' interests; desire leads to approach (AIDA): this entertains you. This remark is only true if the state activities in play, gamble or game to achieve real "playing" from a psychological point of view. Profound, extended and long-lasting scientific studies from animal play behavior to progress in culture of mankind have investigated childhood, adolescence and late adulthood up to simulations in cyberspace century. The results of these studies show clearly that game behavior can be described in at least five stages: 1. Relaxed field; 2. Quasi-experimental operating; 3. Imitating and imagining a "make-believe" world; 4. Selection of regularities; 5. Fairness (respect for the rules: moral and responsibility). The peak or crown of game behavior is called "Game Intelligence". The social-psychological facts of entertainment computing must be taken into consideration when developing present and future inventions.
\end{abstract}

\section{References}

[1] Kauke, Marion (1992). Spielintelligenz. Spielend lernen - Spielen lehren? Spektrum Akademischer Verlag Heidelberg, Berlin, New York.

[2] Kauke, Marion (1998). Kooperative Intelligenz. Sozialpsychologische und spielexperimentelle Grundlagen der Interaktivität zwischen Partnern. Spektrum Akademischer Verlag Heidelberg 